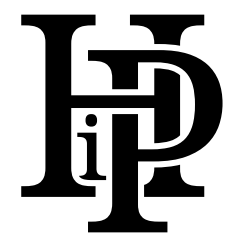

\title{
Marcin CZYŻNIEWSKI
}

Nicolaus Copernicus University, Faculty of Political Science and Security Studies, Toruń, Poland

\section{The Dynamics of the Party System in the Czech Republic}

\author{
Dynamika systemu partyjnego Republiki Czeskiej
}

\section{- Abstract •}

The article examines the changes that took place in the Czech party system from the moment of the political transformation of 1989/1990 to the last parliamentary elections in 2017. It is based on a survey of data on the results of the elections to the Czech National Council and the Chamber of Deputies. The interpretation of the data allows answering several research questions: Is the Czech party system stable, and if so, is it possible to determine its model? Are the inevitable model changes sudden or evolutionary as a consequence of an observable trend? Is it possible to distinguish and define the stages of functioning of the Czech party system? To what extent does the party system of the Czech Republic have roots in the party system of Czechoslovakia and did the disintegration of the federal republic significantly affect its change?

Keywords: party system; the Czech Republic; parliamentary elections

\section{- Abstrakt •}

W artykule przeanalizowano zmiany, jakie zachodziły w czeskim systemie partyjnym od momentu transformacji ustrojowej na przełomie 1989 i 1990 roku do ostatnich wyborów parlamentarnych w 2017 roku. Podstawą badania stała się analiza danych dotyczących wyników wyborów do Czeskiej Rady Narodowej i Izby Poselskiej. Interpretacja danych pomogła odpowiedzieć na szereg pytań badawczych: Czy czeski system partyjny jest stabilny, a jeśli tak, czy można zdefiniować jego model? Czy nieuniknione zmiany modelu przebiegały nagle, czy też w drodze ewolucji jako wynik dającego się zaobserwować trendu? Czy można wyróżnić i zdefiniować etapy funkcjonowania czeskiego systemu partyjnego? W jakim stopniu system partyjny Republiki Czeskiej wyrasta z systemu partyjnego Czechosłowacji i czy rozpad federacji znacząco wpłynął na jego zmianę?

Słowa kluczowe: system partyjny; Republika Czeska; wybory parlamentarne 
Western political science became interested in the stability of political systems quite late. The systems functioning in the West after World War II were permanent and stable, and subsequent elections brought small changes, gaining a certain dynamics only in the early 1970s. The real breakthrough, however, was the fall of communism and the emergence of new democratic regimes in Central and Eastern Europe. Those regimes have become an interesting subject of research, also due to their dynamics and variability. In 1979, Mogens Pedersen proposed an index for determining the variability of electoral preferences between two consecutive elections based on the sum of changes in the electoral results of individual parties (Pedersen, 1979, pp. 1-26). However, it was already clear at that time that the study of the stability of the political system is not simple, because there is no consensus on what should really be studied and what data should be compared. The narrowest view is limited to the parties that made it to the parliament, but other authors examine all parties taking part in the elections, regardless of their success. What is important is the variability in the composition of the parliament, but also changes in the number of seats won by individual parties and the success of new parties. The authors agree that the most accurate index, based on numerical data, is only statistical, and the study of the party or, more broadly, political system also requires qualitative research. Michalak (2008, p. 7) emphasizes that the stability of the party system does not consist in the constant presence of the same political parties in the parliament, but in the permanence of their links with specific social groups.

The article examines the changes that took place in the Czech party system from the moment of the political transformation of 1989/1990 to the last parliamentary elections in 2017. It is based on a survey of data on the results of the elections to the Czech National Council $(1990,1992)$ and the Chamber of Deputies of the Parliament of the Czech Republic (1996, 1998, 2002, 2006, 2010, 2013, 2017). Changes in the composition of the parliament of subsequent terms, especially those immediately following each other, including changes in electoral support for individual parties, are particularly important. The interpretation of the data will allow answering several research questions: Is the Czech party system stable, and if so, is it possible to determine its model? Are the inevitable model changes sudden or evolutionary as a consequence of an observable trend? Is it possible to distinguish and define the stages of functioning of the Czech party system? To what extent does the party system of the Czech Republic have roots in the party system of Czechoslovakia and did the disintegration of the federal republic significantly affect its change? A quantitative study of the dynamics of the party system can be an introduction to the study of the causes of changes, which also constitute a system created on the basis of interconnectedness: on the one hand, the voters them- 
selves and their preferences change; on the other hand, the offer of political parties changes (some disappear, others arise, merge, etc.).

At the beginning of the democratic party system in Czechoslovakia after the Velvet Revolution, there were three groups of political parties: a) parties functioning within the communist regime and continuing their functioning, b) parties claiming to be continuators of parties operating before 1948, or which transformed from groups of dissidents operating during the communist period, and c) newly formed parties (Bureš \& Just, 2010, p. 41). Already in 1990, 66 parties were registered in Czechoslovakia, 23 of them took part in the elections to the Federal Assembly and 13 to the Czech National Council (Cabada \& Šanc, 2005, p. 115). At the turn of 1990, the dominant position in the Czech part of the federal republic was held by the Civic Forum (Občanské fórum, OF), which, paradoxically, was not a political party, but a movement without structures, membership declarations and formal leadership, with a very wide ideological spectrum. The Civic Forum decisively won the first parliamentary elections in June 1990, both in the Czech part of the Federal Assembly and in the Czech National Council.

Table 1. Distribution of Seats in the Czech National Council after the 1990 Elections

\begin{tabular}{|c|c|c|c|c|}
\hline Party & OF & KSČ & HSD-SMS & KDU \\
\hline $\begin{array}{c}\text { Number of seats } \\
\text { (percentage of votes) }\end{array}$ & $\begin{array}{c}124 \\
(49,5)\end{array}$ & $\begin{array}{c}33 \\
(13,24)\end{array}$ & $\begin{array}{c}23 \\
(10,03)\end{array}$ & $\begin{array}{c}20 \\
(8,42)\end{array}$ \\
\hline
\end{tabular}

Source: The Czech Statistical Office (n.d.).

The Civic Forum introduced 124 deputies to the Czech National Council. Since then, no Czech political party has come close to such a result, or even won an independent majority. The first elections were a popularity contest between the old and the new; the classic dividing lines began to form only after 1990 and made themselves felt in the subsequent elections of 1992 (Bureš \& Just, 2010, p. 57). However, the results of the first democratic elections have already revealed the shape of the future party system in the Czech Republic to some extent. From this perspective, the success of the Communist Party (Komunistická strana Ceskoslovenska, $K S \check{C}$ ) was the most important: it won $13.24 \%$ of the votes and 33 seats in the Czech National Council. If the 1990 elections are considered a popularity contest, the result of the Communists was a success. As Kopeček $\&$ Pšeja (2008, p. 322) write, the entry of the communist party into the parliament, and from the second place at that, provided them with a social legitimacy and removed the threat of them being banned. The result of this electoral test 
marked the fate of the Communists for good, making them a strong and permanent element of the Czech political system to this day. The Czech National Council also included deputies from the HSD-SMS (Hnuti za samosprávnou demokracii - Společnost pro Moravu a Slezsko, Movement for Autonomous Democracy - Association for Moravia and Silesia) list working for the autonomy of Moravia and Silesia within the federal republic, and the coalition KDU (Krestanská a demokratická unie, Christian Democratic Union). Only 4 parties participated in the distribution of seats. At the same time, it was a parliament in which almost a fifth of voters did not have a representative. As many as $18.81 \%$ of the votes were cast for parties that did not cross the electoral threshold, which becomes even more significant if we take into consideration the record turnout of $96.79 \%$.

The Civic Forum ceased to exist in 1991. The reason was the emergence of a strong right wing, which transformed into a separate party: ODS (Občanská demokratická strana, Civic Democratic Party). This resulted in the formation of five new parliamentary clubs in the Czech National Council and the flow of deputies between the parties and the government/opposition. Of the 124 members of the Civic Forum, 43 went to the $\mathrm{OH}$ (Občanská hnutí, Civic Movement) club, 41 to the ODS club, 9 to the ODA (Občanská demokratická aliance, Civic Democratic Alliance), 5 created the Roma Civic Initiative (ROI, Romská občanská iniciativa) club, and 5 went to the LDS (Liberálné demokratická strana, Liberal Democratic Party) club. One member of the Civic Forum decided to move to another parliamentary party, KDS (Křestanskodemokratická strana, Christian Democratic Party), and 20 remained non-party deputies (Poslanci České národní rady, 1992). At that time, even bigger changes took place in the Federal Assembly: in 1990, 9 parties won the seats; two years later, the deputies represented 27 groups (Vodička \& Cabada, 2007, p. 298).

The first democratically elected parliaments (Czech, Slovak, Federal) were to adopt the basic legal acts establishing the constitutional order and it was agreed in advance that their terms of office would last only 2 years. The results of the 1992 elections show that it was the first parliamentary term that was the actual beginning of the formation of the Czech party system. The distribution of seats in the Czech National Council elected in 1992 shows how dynamic the nature of the changes was. 
Table 2. Distribution of Seats in the Czech National Council after the 1992 Elections

\begin{tabular}{|c|c|c|c|c|c|c|c|c|}
\hline Party & $\begin{array}{c}\text { ODS- } \\
\text {-KDS }\end{array}$ & LB* $^{*}$ & ČSSD & LSU** $^{* *}$ & $\begin{array}{c}\text { KDU- } \\
\text {-ČSL** }\end{array}$ & $\begin{array}{c}\text { SPR- } \\
\text {-RSC }\end{array}$ & ODA & $\begin{array}{c}\text { HSD- } \\
\text {-SMS }\end{array}$ \\
\hline $\begin{array}{c}\text { Number of seats } \\
\text { (percentage of votes) }\end{array}$ & $\begin{array}{c}76 \\
(29,73)\end{array}$ & $\begin{array}{c}35 \\
(14,05)\end{array}$ & $\begin{array}{c}16 \\
(6,53)\end{array}$ & $\begin{array}{c}16 \\
(6,52)\end{array}$ & $\begin{array}{c}15 \\
(6,28)\end{array}$ & $\begin{array}{c}14 \\
(5,98)\end{array}$ & $\begin{array}{c}14 \\
(5,93)\end{array}$ & $\begin{array}{c}14 \\
(5,87)\end{array}$ \\
\hline
\end{tabular}

* LB: Levý blok, The Left Bloc, ** LSU: Liberálnè sociálni unie, Liberal-Social Union, ${ }^{* * *}$ KDU-ČSL, Krestanská a demokratická unie - Československá strana lidová, Christian and Democratic Union Czechoslovak People's Party

Source: The Czech Statistical Office (n.d.).

Candidates from 8 committees, representing 11 political parties, entered the Czech National Council (three coalition lists were issued in the elections). For the next 25 years, the Czech parliament has not been this fragmented, the situation was repeated only after the 2017 elections. During the term of office, there were additional divisions of the existing clubs. Among others, the Left Bloc coalition has been divided, and some of the KDS deputies, which had previously formed a coalition with ODS, formed a joint club with KDU-ČSL (Kopecký, Hubáček, \& Plecitý, 1996, p. 442). In the 1992-1996 term, nine opposition deputies switched to the ruling coalition, and one deputy from the ruling party joined the opposition the government majority increased from 105 to 112 deputies. Internal dynamics in the parliament led to the introduction of new chamber rules in 1995, which were to hinder the movement of deputies between clubs and the formation of new clubs (Linek \& Mansfeldová, 2007, pp. 18-19). The 1992 elections confirmed ODS’ position among the parties originating from the Civic Forum. $\mathrm{OH}$, which in the previous term took over the largest number of deputies from the Civic Forum, did not enter the parliament at all - the OH list won $4.59 \%$ of the votes; and ODA introduced 14 deputies. The Communist Party, despite a good result in 1990, decided not to put up its own list, but formed a coalition with smaller parties and left-wing movements under the name of the Levy blok. The result of this coalition was much worse than that of the Communists in 1990, and shortly after the election the coalition began to disband. The Communist Party (under the new name, The Communist Party of Bohemia and Moravia, Komunistická strana Čech a Moravy, KSČM), decided to build its own identity and position, all the more so because competition began to grow on the left in the form of ČSSD (Česká strana sociálně demokratická, Czech Social Democratic Party). ČSSD considered itself to be a historical party, referring to the Social Democratic Party formed in the nineteenth century. After the communist coup in 1948, ČSSD was incorporated into the Communist Party, but 
some activists rebuilt it in exile. The far right, which was the established in February 1990 SPR-RSČ (Sdružení pro republiku - Republikánská strana Československa, The Rally for the Republic - Republican Party of Czechoslovakia), also entered the Czech National Council for the first time. The Czech parliament elected in 1992 was, therefore, not only highly fragmented, but also presented a whole spectrum of ideologies, from the extreme post-communist left to the extreme right.

The term of office 1992-1996 was the term when the Czech and Slovak Federal Republic was abolished. The Czech National Council was not dissolved, but on January 1, 1993, it was transformed into the parliament of the independent Czech Republic: the Chamber of Deputies (Poslanecká snémovna) with the same deputies. The results of the first elections to the Chamber of Deputies in 1996 indicated that the party system of the Czech Republic was already formed and stable. Only those political parties that had their representatives in the Czech National Council elected during the period of the federal republic were included in the parliament.

Table 3. Distribution of Seats in the Chamber of Deputies after the 1996 Elections

\begin{tabular}{|c|c|c|c|c|c|c|}
\hline Party & ODS & ČSSD & KSČM & $\begin{array}{c}\text { KDU- } \\
\text { - ČSL }\end{array}$ & SPR-RSČ & ODA \\
\hline $\begin{array}{c}\text { Number of seats } \\
\text { (percentage of votes) }\end{array}$ & $\begin{array}{c}68 \\
(29,62)\end{array}$ & $\begin{array}{c}61 \\
(26,44)\end{array}$ & $\begin{array}{c}22 \\
(10,33)\end{array}$ & $\begin{array}{c}18 \\
(8,08)\end{array}$ & $\begin{array}{c}18 \\
(8,01)\end{array}$ & $\begin{array}{c}13 \\
(6,36)\end{array}$ \\
\hline
\end{tabular}

Source: The Czech Statistical Office (n.d.).

ODS was the winner of the election for the second time, but its position was weaker than in 1992.

The merger with KDS turned out to be a mistake, the Christian Democrat voters did not transfer their votes to ODS. In total, the ODS-KDU-ČSL-ODA coalition, which formed the Czech government in 1992-1996, had 6 fewer deputies in the new term, which was the result of ODS' weaker election result. ODS' leader, Václav Klaus, decided to maintain the coalition, which, however, did not have a majority. The establishment of a minority government and disputes both within the coalition and within ODS itself meant that the first Chamber of Deputies lasted only 2 years.

The real winner of the 1996 elections was ČSSD. Support for the Social Democrats increased from $6.53 \%$ to $26.44 \%$ in 4 years, and the number of deputies increased from 16 to 61 . The author of the party's success was its new leader, Miloš Zeman. He based the party's strategy on harsh criticism of the market economy and building up the Social Democrats as a real alternative to the right-wing and 
free-market ODS (Cabada \& Šanc, 2005, p. 126). The main victim of ČSSD's success were the Communists, who lost the struggle for leadership on the left. In the years 1992-1996, there were significant ideological changes within KDU-ČSL. In the face of a declining support, they muted the worldview-related issues focusing on the social issues instead. In opposition to ODS and ODA, the KDU-ČSL coalition began to advocate the so-called social market economy (Cabada \& Šanc, 2005, p. 126). Autonomists from HSD-SMS did not enter the Chamber of Deputies.

The early elections to the Chamber of Deputies in 1998 were the result of the government crisis. In 1997, KDU-ČSL and ODA broke off the coalition due to ambiguities regarding the financing of ODS, and within ODS itself there was a struggle for leadership. Václav Klaus retained control of his party, but some of the members formed a new party: US (Unie svobody, Freedom Union). The 1998 elections brought about the first major change in the Czech party system - ODS lost the power it had assumed during the federal republic, and the new government was formed by ČSSD, for the first time since its reactivation (Czyżniewski, 2014, p. 92). The right-wing SPR-RSČ was missing from the parliament, thus the ideological spectrum of the Chamber of Deputies moved to the left. The coming to power of the left-wing party a few years after the political changes of 1989/1990 was also the experience of other countries in the region (e.g., of Poland in 1993), but in the Czech Republic it was not the post-communist left, i.e., originating from the party ruling before 1989 .

Table 4. Distribution of Seats in the Chamber of Deputies after the 1998 Elections

\begin{tabular}{|c|c|c|c|c|c|}
\hline Party & ČSSD & ODS & KSČM & KDU-ČSL & US \\
\hline $\begin{array}{c}\text { Number of seats } \\
\text { (percentage of votes) }\end{array}$ & $\begin{array}{c}74 \\
(32,31)\end{array}$ & $\begin{array}{c}63 \\
(27,74)\end{array}$ & $\begin{array}{c}24 \\
(11,03)\end{array}$ & $\begin{array}{c}20 \\
(9)\end{array}$ & $\begin{array}{c}19 \\
(8,60)\end{array}$ \\
\hline
\end{tabular}

Source: The Czech Statistical Office (n.d.).

Despite their electoral success, the Social Democrats were unable to form a majority government. The main reason was the attitude of US, which did not want to form a coalition with ČSSD. The unwritten agreement ruled out forming a coalition with the Communists, but even such a coalition would not have a majority of 101 votes. Eventually, ČSSD formed a minority government, supported on the most important issues by the opposition in the form of ODS. The two parties that built their election campaigns on emphasizing their differences had many common interests, and one of them was the monopolization of Czech politics. As part of the so-called "Opposition Agreement", a package of laws amending the electoral 
law was adopted to strengthen the strongest parties (in practice, ODS and ČSSD). A new system for converting votes into seats was established, a modified d'Hondt system in place of the Hagenbach-Bischoff system, with a simultaneous increase in the number of constituencies (Novák, 2000, p. 38). The electoral threshold for the coalition has been raised. If the new system had come into force before the 1998 elections, ČSSD would have won 100 seats instead of 74 seats, ODS 88 instead of 63, but the smaller parties would have lost a total of 45 seats (Czyżniewski, 2012, p. 228). Most of the proposed changes have not entered into force. The Constitutional Court ruled that they would constitute a departure from the proportional electoral system enshrined in the Constitution.

Although ČSSD's cooperation with ODS provoked a wave of public criticism, the 2002 elections recreated the arrangement in the Chamber of Deputies from 4 years before.

Table 5. Distribution of Seats in the Chamber of Deputies after the 2002 Elections

\begin{tabular}{|c|c|c|c|c|}
\hline Party & ČSSD & ODS & KSČM & $\begin{array}{c}\text { KDU-ČSL, } \\
\text { US-DEA }\end{array}$ \\
\hline $\begin{array}{c}\text { Number of seats } \\
\text { (percentage of votes) }\end{array}$ & $\begin{array}{c}70 \\
(30,20)\end{array}$ & $\begin{array}{c}58 \\
(24,47)\end{array}$ & $\begin{array}{c}41 \\
(18,51)\end{array}$ & $\begin{array}{c}31 \\
(14,21)\end{array}$ \\
\hline
\end{tabular}

Source: The Czech Statistical Office (n.d.).

ČSSD and ODS lost a total of 9 seats. Noteworthy, however, is the significant increase in support for KSČM - it was the communists who have become the main beneficiary of the dissatisfaction of part of the public with the Opposition Agreement. In the election campaign, KSČM presented itself as a real alternative to the dominant parties, which had never been associated with the government and was not responsible for the negative effects of the economic transformation. Small centrist parties have also tried to take advantage of the dissatisfaction with the Opposition Agreement. US, which merged with DEU (Demokratická unie, Democratic Union) in 2001, formed an electoral coalition with KDU-ČSL. In total, the candidates of this coalition won 31 seats, which is less than the candidates of KDU-ČSL and the Freedom Union combined in 1998. A large part of the Czechs discouraged by the Opposition Agreement simply did not take part in the elections. In 2002, there was a record low voter turnout, with only $58 \%$.

The 2006 elections not only maintained the current parliamentary system, strengthening the dominant position of the two largest parties: ODS and ČSSD, which won a total of 155 seats, while the other parties won only 45 . At the same 
time, the elections confirmed the greatest weakness of this arrangement: the difficulty in building a stable parliamentary majority. In 2006, the situation became a stalemate: the centre-right parties and the left-wing parties won the same number of seats.

Table 6. Distribution of Seats in the Chamber of Deputies after the 2006 Elections

\begin{tabular}{|c|c|c|c|c|c|}
\hline Party & ODS & ČSSD & KSČM & KDU-ČSL & SZ \\
\hline $\begin{array}{c}\text { Number of seats } \\
\text { (percentage of votes) }\end{array}$ & $\begin{array}{c}81 \\
(35,38)\end{array}$ & $\begin{array}{c}74 \\
(32,32)\end{array}$ & $\begin{array}{c}26 \\
(12,81)\end{array}$ & $\begin{array}{c}13 \\
(7,22)\end{array}$ & $\begin{array}{c}6 \\
(6,29)\end{array}$ \\
\hline
\end{tabular}

Source: The Czech Statistical Office (n.d.).

ODS won the elections, significantly increasing the number of deputies, but above all it confirmed its dominant position among centrist and right-wing parties. US-DEU, despite attempts to reach young voters with a strongly liberal message, won only $0.3 \%$ of the votes and never returned to the parliament. The stable $2+1+2$ system was supplemented in the 2006-2010 term by SZ (Strana zelených, Green Party).

The elections in 2010 were the first violation of the stability of the party system and a harbinger of profound changes in the future (Charvát, 2014).

Table 7. Distribution of Seats in the Chamber of Deputies after the 2010 Elections

\begin{tabular}{|c|c|c|c|c|c|}
\hline Party & ČSSD & ODS & TOP09 & KSČM & VV \\
\hline $\begin{array}{c}\text { Number of seats } \\
\text { (percentage of votes) }\end{array}$ & $\begin{array}{c}56 \\
(22,08)\end{array}$ & $\begin{array}{c}53 \\
(20,22)\end{array}$ & $\begin{array}{c}41 \\
(16,70)\end{array}$ & $\begin{array}{c}26 \\
(11,27)\end{array}$ & $\begin{array}{c}24 \\
(10,88)\end{array}$ \\
\hline
\end{tabular}

Source: The Czech Statistical Office (n.d.).

ČSSD and ODS maintained their dominant positions as two most important parties, but their joint result (109 deputies) was the worst in history. The Communist Party retained its possession (26 deputies), but ceased to be the third force in the parliament. All parties that were in the Chamber of Deputies for the second time in a row received worse support (in percent) than 4 years earlier and this was the first such case since 1992. The biggest change was the entry of two new parties, TOP09 and VV (Vèci verejné, Public Affairs), into the Chamber and the fact that both of these parties were formed after the collapse of the federal republic. Taking into consideration the support for all political parties taking part in the elections, including those that did not exceed the threshold, it can be concluded that 
in 2010 as many as $38.5 \%$ of votes were cast for parties that were created in the previous two years. Until then, since 1996, this support has never exceeded $11 \%$ (Czyżniewski, 2018, p. 137). The balance of power, and especially the good result of the two smaller centrist parties, allowed for the first time to build a clear majority - the government had the support of 118 deputies (the ODS-TOP09-VV coalition). However, for the first time since 1990, the government coalition was not formed by the party that received the most votes (ČSSD). The government majority was substantial, but it turned out to be unstable. Two years after the elections, there was a split in the VV party and the transition of some deputies to the opposition. The ODS-TOP09 government finally collapsed in 2013.

The early elections in 2013 brought about the most serious changes on the political scene since 1993. As many as seven parties entered the Chamber of Deputies, and the ČSSD/ODS monopoly was partially broken. ČSSD won the election, but achieved the worst result since 1992 (in percentage terms it lost little compared to 2010), while for ODS the elections were a disaster - one of the two most important political parties in the country won only 16 seats. On the other hand, the previous arrangement with two dominant parties and the Communists as the third force partially survived. The election brought success to the new populist ANO party. Another populist party, Úsvit (Úsvit prímé demokracie Tomia Okamury, Tomio Okamura's Dawn of Direct Democracy), founded a few months before the elections, was also successful.

Table 8. Distribution of Seats in the Chamber of Deputies after the 2013 Elections

\begin{tabular}{|c|c|c|c|c|c|c|c|}
\hline Party & ČSSD & ANO & KSČM & TOP09 & ODS & Úsvit & $\begin{array}{c}\text { KDU- } \\
\text { ČSL }\end{array}$ \\
\hline $\begin{array}{c}\text { Number of seats } \\
\text { (percentage of votes) }\end{array}$ & $\begin{array}{c}50 \\
(20,45)\end{array}$ & $\begin{array}{c}47 \\
(18,65)\end{array}$ & $\begin{array}{c}33 \\
(14,91)\end{array}$ & $\begin{array}{c}26 \\
(11,99)\end{array}$ & $\begin{array}{c}16 \\
(7,72)\end{array}$ & $\begin{array}{c}14 \\
(6,88)\end{array}$ & $\begin{array}{c}14 \\
(6,78)\end{array}$ \\
\hline
\end{tabular}

Source: The Czech Statistical Office (n.d.).

For the first time, there was a situation in which the two dominant parties formed a government coalition. However, due to the large fragmentation of the Chamber of Deputies, they did not have a majority (4 votes were missing). For the first time since 1996, the two winning parties did not have more than half of the seats in the parliament. Eventually, an exotic coalition of the Social Democrats with the populist ANO and the centre-right KDU-ČSL, which returned to the Chamber of Deputies, was built. 
The results of the 2017 elections were a continuation of a trend that emerged in 2010 and was strengthened in 2013.

Table 9. Distribution of Seats in the Chamber of Deputies after the 2017 Elections

\begin{tabular}{|c|c|c|c|c|c|c|c|c|c|}
\hline Party & ANO & ODS & $\begin{array}{c}\text { Piráti } \\
\text { (Pirats) }\end{array}$ & SPD & KSČM & CSSD & $\begin{array}{c}\text { KDU- } \\
\text {-ČSL }\end{array}$ & $\begin{array}{c}\text { TOP } \\
\text { 09 }\end{array}$ & STAN \\
\hline $\begin{array}{c}\text { Number of seats } \\
\text { (percentage of votes) }\end{array}$ & $\begin{array}{c}78 \\
(29,64)\end{array}$ & $\begin{array}{c}25 \\
(11,32)\end{array}$ & $\begin{array}{c}22 \\
(10,79)\end{array}$ & $\begin{array}{c}22 \\
(10,64)\end{array}$ & $\begin{array}{c}15 \\
(7,76)\end{array}$ & $\begin{array}{c}15 \\
(7,27)\end{array}$ & $\begin{array}{c}10 \\
(5,80)\end{array}$ & $\begin{array}{c}7 \\
(5,31)\end{array}$ & $\begin{array}{c}6 \\
(5,18)\end{array}$ \\
\hline
\end{tabular}

Source: The Czech Statistical Office (n.d.).

No longer were there two dominant political parties, but one leader, three parties that introduced more than 20 deputies and 4 smaller representations. In total, in the Chamber of Deputies there were deputies from 9 lists, which is the most in the history of the Czech Republic. The most successful parties have been the parties without an obvious ideological image, which are difficult to even place on the classical left-right axis, and which do not present in their program a compact vision consistent with one of the classical ideologies (ANO, SPD, Piráti, STAN). Three new parties entered the parliament (SPD was a new version of the Usvit), which was also unprecedented in the history of the Czech parliamentary elections. The biggest losers of the election were both left-wing parties. ČSSD and KSČM achieved the worst electoral result in the history of their independent running in the elections, and their position in the parliament was equal. After the emergence of new anti-system parties (SPD, Piráti), the communists ceased to be treated as the only alternative to the existing political system.

The Velvet Revolution, the political transformation and the liquidation of the Communist Party's monopoly of power created new conditions for the development of a democratic, pluralistic party system in Czechoslovakia, including the Czech part of the federal republic. As in all countries of the region, this has led to the spontaneous development of political parties, primarily in terms of numbers, not structures and organizations. The first parliamentary elections, held six months after the political changes, became the foundation of the future party and political system, but it was only during the term of the first parliament that the future stable system began to develop for good. It can, therefore, be said that the Czech party system was not revolutionary, it did not preserve the balance of political forces from the period of the regime change itself, but evolutionary, created thanks to the democratic mechanisms of competition of political parties. It was the activity of political parties in the parliament, participation in the introduction of political, 
economic, and social changes, and the publicly formulated attitude to these changes that determined the position of individual parties and their place in the system. ODS gained a dominant position among the parties that grew out of the disbanded Civic Forum in large part because the founder and leader of this party, Václav Klaus, was the main architect of the economic transformation. The 1996 elections gave the Czech parliament a form that was to survive for four consecutive terms: ODS and ČSSD as the two strongest parliamentary parties, KSČM as the third force with a high support, but not part of the government coalition, and two smaller parties, which were important in building a coalition. It was a stable multi-party system with two dominant parties.

The collapse of the Czech and Slovak Federal Republic did not change the composition of the parliament, which indicated not only the stabilization of the political system, but also the fact that for the Czechs the independent Republic was simply a continuation of the Czech state traditions from the period of the common Czechoslovakia. The disintegration of the federal republic, which has existed for almost 70 years, should have brought about profound changes in the political situation, including the party system. Meanwhile, the Czech parliament survived this disintegration without any upheavals, and in the next term of office there was not a single new party in it. This state of affairs was influenced by the fact that within the federal republic the Czech and Slovak party systems developed separately and autonomously, in both parts of the state other parties were formed and operated (this even applied to the Civic Forum, which was a Czech movement, and its Slovak counterpart was the HZDS movement). The first political party that was not formed during the Czechoslovak period entered parliament only in 1998 (US), but in 2006 again all parliamentary parties had Czechoslovak traditions. The situation began to change for good since the 2010 elections, when two parties formed after the collapse of the federal republic entered the Chamber of Deputies, taking a total of 66 seats. Already three years later, three parties established after 1993 had their representatives in the Chamber of Deputies, and the number of deputies representing them increased to 77. This trend deepened after the next elections, in 2017. Of the 9 parliamentary parties, five did not have Czechoslovak traditions. At the beginning, it was mentioned that in Czechoslovakia, and then in the Czech Republic, there were three groups of parties, taking into consideration their historical tradition. The analyzed data show that during the period of formation of the party system, this division did not matter to the voters.

The development of the Czech political system at an early stage led to a shift of liberal ideas (especially concerning the economy) to the right side of the political scene, which was not obvious in the reality of post-communist states at that time 
(Kopeček, 2001, pp. 244-271). On the left, on the other hand, a stable, strong leftwing bloc with a clear social and statist agenda has formed. Despite some difficulties in defining the Czech political parties on the left-right axis, it can be considered that until 2017 there was a certain balance between left and right in the Chamber of Deputies in terms of the number of deputies (ideal in 2006). The 2017 elections upset this balance and thus the traditional strength of left-wing parties in the parliament. This does not mean strengthening the centrist and right-wing forces, rather we were dealing with a system of left-wing parties/parties without a specific ideological character. In 2013, the first and third places were taken by two left-wing parties with a clear and consistent ideological message - the Social Democrats and the Communists, and the next two by the right-wing ODS and the centre-right TOP09. In 2017, ODS took the second place, but in the election campaign it abandoned the current image of the classic conservative-liberal party in favor of a rather shallow rhetoric of opposition to the European Union and the admission of refugees (Czyżniewski, 2018, pp. 140-141).

The Czech political system has traditionally been considered the most stable of all post-communist states in Europe (Birch, 2003; Antoszewski, 2007, pp. 19-21). However, there is no consensus in the literature as to why the Czech system showed such a stability compared to other countries of Central and Eastern Europe (Deegan-Krause \& Haughton, 2010), which is still a topic of research and discussion. Taking into consideration the data presented, it can be concluded that the development of the Czech party system has so far taken place in four periods: the formation of the system (1990-1992), the stabilization of the system (1992-2010), the correction of the system (2010-2013), the change of the system (after 2013). The data confirm that regardless of the changes and their scope, the Czech party system is stable. Even the deepest changes did not occur suddenly, but were part of an observable trend. In the Czech party system, we can notice the element of instability: it is a difficulty in building a clear and stable parliamentary majority. Three times it was necessary to establish a minority government, and majority rule was based on one or several deputies. Paradoxically, this feature of the system is due to its stability. In a situation in which two parties opposing each other win the most seats, the Communists do not have the ability to form a coalition, and the number of deputies of the other parties is relatively small, there is no arithmetic possibility to build an independent majority, and the coalition can count on only a slight advantage in the Chamber. It would seem that the profound change in the balance of power in the Chamber of Deputies in 2017, its fragmentation, the breaking of the ČSSD/ODS monopoly and the weakening of the Communist Party allowed building a stable majority, but this time the reluctance of political parties to 
cooperate with ANO has stood in the way. This confirms that although quantitative research allows for understanding of the dynamics of changes in the system, it must form the basis for qualitative research to explain the causes and dependencies.

\section{References:}

Antoszewski, A. (2007). Systemy partyjne Europy Środkowej i Wschodniej. In: K. Kowalczyk, \& Ł. Tomczak (Eds.). Czechy, Polska, Ukraina. Partie i systemy partyjne. Stan i perspektywy (pp. 7-26). Toruń: Wydawnictwo Adam Marszałek.

Birch, S. (2003). Electoral Systems and Political Transformation in Post-Communist Europe. Basingstoke-New York: Palgrave.

Bureš, J. (2011). Československý parlament v roce 1989. In: V. Doubek, M. Polášek et al. (Eds.). Parlament v čase zmèny. Př́padové studie z vývoje českého a československého parlamentarismu (pp. 123-148). Praha: Akropolis.

Bureš, J., \& Just, P. (2010). The Origin of the Czech and Slovak Pluralist Party Systems. Politics in Central Europe, 6(1), 41-82.

Cabada, L., \& Šanc, D. (2005). Český stranický system ve 20. století. Plzeň: Vydavatelství a nakladatelství Aleš Čeněk.

Charvát, J. (2014). The Czech Party System Change since 2010: From Fragile Stability to Stable Fragility. Revista de Stiinte Politice, 41, 141-154.

The Czech Statistical Office (n.d.). Retrieved from: www.volby.cz.

Czyżniewski, M. (2012). Idee w polityce Václava Klausa. Toruń: Wydawnictwo Naukowe Uniwersytetu Mikołaja Kopernika.

Czyżniewski, M. (2014). Zmiana systemu partyjnego Republiki Czeskiej po wyborach do Izby Poselskiej w 2013 roku. Studia Wyborcze, 17, 91-109.

Czyżniewski, M. (2018). Wybory do Izby Poselskiej w 2017 roku jako wynik zmian politycznych w Republice Czeskiej. Acta Universitatis Lodziensis. Folia Iuridica, 84, 135-147 .

Deegan-Krause, K., \& Haughton, T. (2010). A Fragile Stability: The Institutional Roots of Low Party System Volatility in the Czech Republic, 1990-2009. Politologický časopis - Czech Journal of Political Science, 17(3), 227-241.

Kopeček, L., \& Pšeja, P. (2008). Czech Social Democracy and Its 'Cohabitation' with the Communist Party: The Story of a Neglected Affair. Communist and Post-Communist Studies, 41(3), 317-338. DOI: 10.1016/j.postcomstud.2008.06.005.

Kopecký, P., Hubáček, P., \& Plecitý, P. (1996). Politické strany v českém Parlamentu (1992-1996): organizace, chování a vliv. Sociologické studie, 32(4), 439-456.

Linek, L., \& Mansfeldová, Z. (2007). The Parliament of the Czech Republic, 1993-2004. The Journal of Legislative Studies, 13(1), 12-37. DOI: 10.1080/13572330601165238.

Michalak, B. (2008). Partie protestu w Europie Zachodniej. Analiza relewancji politycznej. Toruń: Wydawnictwo Adam Marszałek.

Novák, M. (2000). The Relevance of Small Parties: From a General Framework to the Czech 'Opposition Agreement'. Czech Sociological Review, 8(1), 27-47. 
Pedersen, M.N. (1979). The Dynamics of European Party Systems: Changing Patterns of Electoral Volatility. European Journal of Political Research, 7(1), 1-26. DOI: 10.1111/ j.1475-6765.1979.tb01267.x.

Poslanci České národní rady (1992). Poslanecká snèmovná Parlamentu České Republiky, digitální repozitár. Retrieved from: https://www.psp.cz/eknih/1990cnr/rejstrik/jmenny/sez.htm.

Šafaříková, V. et al. (1996). Transformace české společnosti 1989-1995. Brno: Nakladatelství Doplnek.

Vodička, K., \& Cabada, L. (2007). Politický systém České republiky. Praha: Portal. 